\title{
SINTESIS NANOPARTIKEL EKSTRAK KULIT MANGGIS MERAH DAN KAJIAN SIFAT FUNGSIONAL PRODUK ENKAPSULASINYA
}

\author{
[Nanoparticle of Red Mangosteen Peel Extract Synthesis and \\ the Functional Characteristics of Its Encapsulated Products]
}

\author{
Nurmalia Ningsih $^{1)}$, Sedarnawati Yasni ${ }^{1) \star}$, dan Sri Yuliani ${ }^{2)}$ \\ ${ }^{1)}$ Departemen IImu dan Teknologi Pangan, Fakultas Teknologi Pertanian, Institut Pertanian Bogor, Bogor \\ ${ }^{2)}$ Balai Besar Penelitian dan Pengembangan Pascapanen Pertanian, Bogor
}

Diterima 14 Maret 2017 / Disetujui 18 Mei 2017

\begin{abstract}
Utilization of mangosteen fruit waste tends to be less practical, so nanoparticle based encapsulation is an effective approach. The objective if this research was to utilize the waste from the red mangosteen peel Garcinia forbesii (GF) and Garcinia mangostana (GM) to produce nanoparticle extract, its encapsulation products, and determine its functional properties. This research consists of three stages: extraction, synthesis of nanoparticle, and encapsulation. The parameters evaluated were the yield of extracts, antioxidant, total phenolic content (TPC), particle size, index of polydispersity, and surface morphology of the encapsulated product. Synthesis of nanoparticles was carried out by using ionic gelation method. The functional values was calculated based on $10 \%$ extracts in the nanoparticles solution. The results showed that extraction by reflux method gave better results than that with maceration. Formula of nanoparticles containing $0.2 \%$ of chitosan concentration and $0.1 \%$ STPP and products encapsulated with casein and maltodextrine gave the best result with increased functional values.
\end{abstract}

Keywords: encapsulation, nanoparticle, red mangosteen skin

\begin{abstract}
ABSTRAK
Pemanfaatan limbah kulit buah manggis cenderung kurang praktis, sehingga enkapsulasi berbasis nanopartikel merupakan pendekatan yang efektif. Tujuan penelitian ini adalah pemanfaatan limbah kulit manggis merah Garcinia forbesii (GF) dan Garcinia mangostana (GM) untuk menghasilkan nanopartikel ekstrak, produk enkapsulasinya, dan mengetahui sifat fungsionalnya. Penelitian ini terdiri dari tiga tahap, yaitu ekstraksi, sintesis nanopartikel, dan enkpasulasi. Parameter yang digunakan adalah rendemen ekstrak, nilai fungsional antioksidan dan Total Senyawa Fenol (TSF), ukuran partikel, indeks polidispersitas, dan morfologi permukaan enkapsulat. Sintesis nanopartikel dilakukan menggunakan metode gelasi ionik. Perhitungan nilai fungsional menggunakan konsentrasi ekstrak sebesar $10 \%$ dalam larutan nanopartikel. Hasil penelitian menunjukkan bahwa menggunakan metode refluks memberikan hasil yang lebih baik dibandingkan dengan metode maserasi. Formula 2 nanopartikel dengan konsentrasi kitosan $0,2 \%$ dan STPP $0,1 \%$ dan produk enkapsulasinya dengan bahan penyalut Maltodekstrin Kasein (MK) memberikan hasil yang terbaik dengan peningkatan nilai fungsional.
\end{abstract}

Kata kunci: enkapsulasi, kulit manggis merah, nanopartikel

\section{PENDAHULUAN}

Salah satu buah Indonesia yang potensial berkhasiat bagi kesehatan adalah buah manggis. Walaupun kulit buah manggis tergolong dalam limbah, namun mengandung senyawa zat aktif yang berkhasiat bagi kesehatan. Buah manggis ada berbagai jenis, salah satunya manggis merah (Garcinia forbesii) atau dikenal dengan nama mundar dan

*Penulis Korespondensi:

E-mail: sedarnawati@yahoo.com manggis biasa (Garcinia mangostana). Komponen zat aktif terdapat dalam kulit manggis di antaranya xanthon, antosianin, tanin, dan senyawa fenolik lainnya. Selain itu juga dilaporkan dapat bertindak sebagai pencegah penyakit degeneratif seperti jantung koroner, kanker, diabetes, hipertensi, struk, dan penyakit alzheimer (Lako et al., 2007). Pada penelitian Randy (2014) dan Mranani (2015) telah dilakukan pengolahan minuman fungsional berbasis Garcinia forbesii dan kajiannya sebagai pengawet alami. Kulit buah manggis merah memiliki aktivitas antioksidan yang tinggi sebesar $2216,6 \pm 1,06 \mathrm{AAE}$ 
$(\mu \mathrm{g} / \mathrm{mL})$. Permasalahan yang terjadi dalam pemanfaatan limbah buah kulit manggis yaitu zat aktifnya sebagai sumber antioksidan alami cenderung kurang praktis, memiliki ketidakstabilan terhadap warna, kelarutan yang rendah, rasa pahit yang kurang diharapkan, mengalami penurunan sifat fungsional selama pengolahan maupun penyimpanan, serta bagaimana melindungi zat aktif kulit buah manggis agar optimum sifat fungsionalnya ketika diaplikasikan dalam produk pangan.

Saai ini teknologi nano banyak dikembangkan dan menjadi tren dalam pengembangan dan peningkatan kualitas produk pangan fungsional. Nano-teknologi sangat berkembang karena memiliki banyak keunggulan seperti ukuran partikel yang lebih kecil memiliki sifat yang khas dibandingkan dengan ukuran partikel yang lebih besar dan fleksibel dikombinasikan dengan teknologi lain sehingga dapat dikembangkan untuk berbagai keperluan. Teknologi nano banyak dikembangkan sebagai penghantar zat aktif dalam suatu produk pangan maupun obat untuk mengatur laju pelepasan senyawa zat aktif, meningkatkan kelarutan, dan meningkatkan penyerapan dalam tubuh. Enkapsulasi berbasis nanopartikel merupakan pendekatan yang efektif dalam memasukkan senyawa bioaktif dalam bahan pangan.

Tujuan penelitian ini adalah melakukan ekstraksi ekstrak Garcinia forbesii dan Garcinia mangostana, sintesis nanopartikel ekstrak Garcinia forbesii dan Garcinia mangostana, menghasilkan produk enkapsulasinya, dan mengetahui sifat fungsionalnya. Penggunaan teknologi nano ini diharapkan berfungsi sebagai pengantar dalam meningkatkan dispersi senyawa bioaktif yang diharapkan dalam produk makanan, melindungi terhadap degradasi mutu yang tidak diinginkan, mengurangi dampak organoleptik yang tidak diharapkan dalam produk makanan, dan meningkatkan bioavailabilitas serta mengontrol penyerapannya dalam saluran pencernaan.

\section{BAHAN DAN METODE}

\section{Bahan}

Bahan yang digunakan dalam penelitian ini terdiri dari manggis merah Garcinia forbesii (GF), manggis Garcinia mangostana (GM) (diperoleh dari konsultan buah-buahan tropis, Mekarsari Bogor), kitosan (diperoleh dari Laboratorium Departemen Teknologi Hasil Perikanan, IPB) dengan derajat deasetilasi (DD) 85\%.

\section{Metode}

Penelitian ini terdiri dari tiga tahapan, yaitu (1) tahap ekstraksi, (2) tahap sintesis nanopartikel, (3) tahap enkapsulasi. Tahap ekstraksi dilakukan dengan dua metode, yaitu maserasi dan refluks dengan tujuan untuk mendapatkan cara ekstraksi kulit manggis dengan hasil yang optimal. Pada ekstraksi dilakukan analisis rendemen, aktivitas antioksidan, dan Total Senyawa Fenol (TSF). Tahap sintesis nanopartikel ekstrak kulit manggis merah dan kulit manggis biasa menggunakan metode gelasi ionik dengan dua perlakuan konsentrasi kitosan dan dua perlakuan konsentrasi Sodium tripolifosfat (STPP). Hasil nanopartikel dianalisis ukuran partikel, indeks polidispersitas, Transmission Electron Microscopy (TEM), aktivitas antioksidan, dan TSF. Formula nanopartikel terpilih dienkapsulasi menggunakan spray dryer dengan dua perlakuan bahan pengisi yaitu kombinasi antara maltodekstrin (M) (Setiaguna, Bogor) dengan derajat ekuivalen DE 13\% dan isolat protein (ISP) (Marksoy 90 Markaindo Corp, Indonesia), dan kombinasi antara maltodekstin (M) dan kasein (K) (Sigma-Aldrich, US). Hasil produk enkapsulasinya dianalisis dengan Scanning Electron Microscopy (SEM), aktivitas antioksidan, dan TSF.

\section{Ekstraksi kulit manggis (Modifikasi Prasad et al., 2009 dan Dewandari et al., 2013)}

Buah manggis dicuci dan dipisahkan antara kulit dan daging buah. Kulit buah manggis dikeringkan dengan suhu $40-50^{\circ} \mathrm{C}$ sekitar 3 jam sampai mencapai kadar air 10-12\%, kemudian digiling dengan ukuran 40 mesh. Ekstraksi kulit manggis akan dilakukan dengan 2 metode, yaitu refluks dan maserasi dengan menggunakan pelarut etanol $70 \%$ (Merck, Germany). Bahan baku ditimbang dan ditambahkan pelarut dengan perbandingan 1:5 (b/v). Waktu ekstraksi refluks yang akan dilakukan sekitar 1 dan 3 jam dengan suhu tidak melebihi $60^{\circ} \mathrm{C}$. Sementara itu, waktu maserasi yang akan dilakukan adalah 6 dan 24 jam pada suhu ruang. Pada masing-masing ampas dilakukan penyaringan dan filtrat dikumpulkan. Pada ampas dilakukan penambahan pelarut dengan perbandingan 1:3. Filtrat dari masing-masing cara dicampurkan dan dipekatkan dengan rotary vaccum evaporator (Buchi R-300, Swizterland) pada suhu $40-45^{\circ} \mathrm{C}$ sampai $20^{\circ}$ brix. Metode ekstraksi dari kedua metode akan dipilih berdasarkan parameter dari rendemen, aktivitas antioksidan, dan TSF (AOAC, 2012).

\section{Sintesis nanopartikel ekstrak kulit manggis (Modifikasi Rismana et al., 2013)}

Sintesis nanopartikel akan dilakukan dengan metode gelasi ionik. Nanopartikel kitosan sebagai penyalut ekstrak kulit manggis akan dibuat dengan mencampurkan STPP (Setia-guna, Bogor), larutan kitosan, dan ekstrak kulit manggis. Larutan kitosan dibuat dengan konsentrasi 0,2 dan $1 \%$. Pembuatan larutan kitosan dengan konsentrasi $0,2 \%$ dilakukan dengan melarutkan $0,2 \mathrm{~g}$ kitosan ke dalam $100 \mathrm{~mL}$ asam asetat glacial (Merck, Germany) 1\% untuk Garcinia mangostana dan asam asetat glacial 0,1\% (Merck, Germany) untuk Garcinia forbesii, demikian 
pula dengan konsentrasi kitosan $1 \%$. Sementara itu, larutan STPP $0,2 \%$ dibuat dengan mencampurkan $0,2 \mathrm{~g}$ STPP ke dalam $100 \mathrm{~mL}$ akuades, begitu pula dengan konsentrasi STPP $0,1 \%$.

\section{Enkapsulasi nanopartikel ekstrak kulit manggis (Modifikasi Desai dan Park, 2005)}

Setelah pembuatan nanopartikel ditambahkan bahan penyalut dengan total padatan $20 \%(\mathrm{~b} / \mathrm{b})$. Bahan penyalut terdiri atas kombinasi antara maltodekstrin $60 \%$ dengan isolat protein kedelai $40 \%$ (MISP), dan kombinasi antara maltodekastrin 60\% dengan kasein 40\% Maltodekstrin Kasein (MK). Setelah itu dilakukan homogenisasi selama 5 menit dengan homogenizer (T25 digital Ultra Turrax), kemudian dihidrasi seama 18 jam pada suhu $4^{\circ} \mathrm{C}$. Setelah dihidrasi sesaat sebelum di spray dying dihomogenisasi kembali selama 30 detik. Spray drying dilakukan dengan Spray Dryer (LabPlant SD05) laju umpan $15 \mathrm{~mL} /$ menit dengan suhu inlet $170^{\circ} \mathrm{C}$ dan tekanan noozle atomizer 1 bar.

\section{Karakterisasi nanopartike dan enkapsulat nano- partikel ekstrak kulit manggis}

Karakterisasi sifat fisik nanopartikel dan produk enkapsulatnya meliputi pengukuran distribusi ukuran partikel indeks polidispersitas menggunakan Particle Size Analyzer (PSA) (Malvern Zetasizer Nano series Nano-ZS, Malvern Instrument, Malvern UK) dengan metode Dynamic Light Scattering. Pengamatan morfologi nanopartikel menggunakan Transmission Electron Microscopy (TEM) (FEI Tenchai G2 Spirit $120 \mathrm{KV}$ ) dengan cara sampel diletakkan pada grid emas dengan ukuran $2,5 \mathrm{~mm}$ yang sangat tipis, lalu didalam tabung ruang hampa elektron akan menuju spesimen yang akan menganalisis ukuran sampel pada perbesaran 500-10000x. Pengamatan morfologi permukaan enkapsulat nanopartikel dilakukan menggunakan Scanning Electron Microscopy (SEM) (ZEISS EVO MA 10) dengan cara sampel enkapsulat ditempelkan pada stub dengan diameter 10 $\mathrm{mm}$ menggunakan pita perekat dua sisi yang dilapisis emas dan diamati morfologi permukaannya pada perbesaran 500-5000x.

\section{Analisis aktivitas antioksidan metode DPPH (Kubo et al., 2002)}

Analisis aktivitas antioksidan dilakukan dengan membuat terlebih dahulu kurva standar menggunakan asam askorbat pada konsentrasi 100, 200, 300, 400, 500, dan 600 ppm. Prosedur pembuatan larutan standar sama dengan pengujian dengan sampel, yaitu dengan memasukkan sebanyak $2 \mathrm{~mL}$ larutan buffer asetat ( $\mathrm{pH} \mathrm{5,5)} \mathrm{dicampurkan} \mathrm{dengan} \mathrm{3,75} \mathrm{mL}$ metanol (Merck, Germany) dan $200 \mu \mathrm{L}$ DPPH (1 mM) (Merck, Germany) kemudian divortex. Larutan standar atau sampel sebanyak $50 \mu \mathrm{L}$ dan divortex kembali dan diinkubasi pada suhu ruang di tempat gelap selama 20 menit. Selanjutnya dilakukan pengukuran absorbansi dengan spektrofotometer pada panjeng gelombang $517 \mathrm{~nm}$. Larutan blanko dibuat sesuai tahapan diatas, namun mengganti $100 \mu \mathrm{L}$ larutan sampel dengan $50 \mu \mathrm{L}$ metanol (Merck, Germany).

\section{Analisis total senyawa fenol (Strychartz dan Shetty, 2002)}

Larutan asam galat (Merck, Germany) yang digunakan untuk membuat kurva standar dibuat dengan melarutkan 10, 25, 50, 75, 100, 125, 150 ppm asam galat dalam akuades. Larutan reagen dibuat dengan menambahkan $50 \mathrm{~mL}$ larutan akuades dan $50 \mathrm{~mL}$ pereaksi Folin Ciocalteaul (Merck, Germany). Sebanyak 0,5 mL larutan standar maupun larutan sampel dalam $2,5 \mathrm{~mL}$ akuades dan $0,5 \mathrm{~mL}$ etanol, lalu dihomogenisasi dan ditambahkan 2,5 $\mathrm{mL}$ larutan reagen. Larutan tersebut didiamkan selama 5 menit dalam ruang gelap, lalu ditambahkan $0,5 \mathrm{~mL} \mathrm{Na}_{2} \mathrm{CO}_{3} 5 \%$ (Setiaguna, Bogor) (agar kondisi basa dan folin bekerja optimum) dan didiamkan kembali dalam ruang gelap selama 1 jam setelah itu diukur nilai absorbansinya pada panjang gelombang $725 \mathrm{~nm}$.

\section{Analisis kadar vitamin C (asam askorbat) (Apri- yantono et al., 1989)}

Larutan $10 \mathrm{~g}$ filtrat sampel dalam $10 \mathrm{~mL}$ larutan asam metaphosfat 5\% (Merck, Germany) - asam asetat $10 \%$ (Merck, Germany) ditambahkan $0,75 \mathrm{mg}$ arang aktif. Hasil saringan ditambahkan 1 tetes pereaksi thiourea 10\% (Merck, Germany) dan $1 \mathrm{~mL}$ larutan dinitrofenilhidrazin (Merck, Germany) (dalam tabung reaksi). Balnko dibuat dengan tahap yang sama tanpa penambahan dinitrofenilhidrazin (diganti air). Tabung reaksi ditempatkan dalam water bath $37^{\circ} \mathrm{C}$ selama 3 jam, lalu didinginkan dalam es. Selanjutnya, ditambahkan $5 \mathrm{~mL} \mathrm{H}_{2} \mathrm{SO}_{4} 85 \%$ (Merck, Germany) dan dibiarkan selama 30 menit, setelah itu diukur nilai absorbansinya pada panjang gelombang $540 \mathrm{~nm}$.

\section{HASIL DAN PEMBAHASAN}

Hasil ekstraksi tepung Garcinia forbesii (GF) dan tepung Garcinia mangostana (GM) pada metode maserasi dan refluks dapat dilihat pada Tabel 1. Perhitungan rendemen dilakukan untuk megetahui efisiensi proses ekstraksi. Rendemen diperoleh dengan membandingkan berat ekstrak (bk) dengan berat bahan kering dikali 100\%. Ekstraksi dengan metode maserasi memberikan rendemen yang lebih kecil dibandingkan dengan refluks. Tingkat polaritas pelarut etanol yang sama dengan zat aktif dalam kulit manggis juga sangat mempengaruhi jumlah zat aktif yang terekstrak. 
Tabel 1. Hasil eksraksi tepung kulit manggis

\begin{tabular}{|c|c|c|c|c|c|}
\hline \multirow{2}{*}{ Parameter } & \multirow{2}{*}{ Sampel } & \multicolumn{2}{|c|}{ Maserasi } & \multicolumn{2}{|c|}{ Refluks } \\
\hline & & 6 jam & 24 jam & 1 jam & 3 jam \\
\hline \multirow{2}{*}{$\begin{array}{l}\text { Rendemen } \\
\text { (\%bk) }\end{array}$} & GF & $31,34 \pm 1,16^{\mathrm{a}}$ & $32,43 \pm 3,07^{a}$ & $41,60 \pm 1,78^{b}$ & $42,00 \pm 1,41^{b}$ \\
\hline & GM & $38,54 \pm 0,54^{c}$ & $40,38 \pm 1,00^{c}$ & $41,67 \pm 0,24^{d}$ & $41,53 \pm 1,51^{\mathrm{d}}$ \\
\hline \multirow{2}{*}{$\begin{array}{l}\text { Aktivitas } \\
\text { antioksidan } \\
\text { AEAC } \mu \mathrm{g} / \mathrm{mL}\end{array}$} & GF & $2550,00 \pm 122,47^{a}$ & $5550,00 \pm 223,60^{\mathrm{b}}$ & $13425,00 \pm 82,91^{\mathrm{c}}$ & $13100,00 \pm 165,83^{d}$ \\
\hline & GM & $2375,00 \pm 268,09^{e}$ & $4975,00 \pm 277,26^{\dagger}$ & $12425,00 \pm 86,60^{9}$ & $10200,00 \pm 82,91^{\mathrm{h}}$ \\
\hline \multirow{2}{*}{$\begin{array}{l}\text { Total senyawa } \\
\text { fenol (TSF) } \\
\text { GAE } \mu \mathrm{g} / \mathrm{mL}\end{array}$} & GF & $291,85 \pm 2,37^{a}$ & $370,65 \pm 3,43^{\mathrm{b}}$ & $785,87 \pm 4,61^{\mathrm{C}}$ & $861,41 \pm 3,21^{a}$ \\
\hline & GM & $4078,80 \pm 27,74^{\mathrm{e}}$ & $4546,00 \pm 11,53^{\dagger}$ & $5105,98 \pm 218,12^{g}$ & $5793,48 \pm 24,90^{\mathrm{n}}$ \\
\hline \multirow[t]{2}{*}{$\mathrm{pH}$} & GF & 2,65 & 2,69 & 2,51 & 2,85 \\
\hline & GM & 2,92 & 2,74 & 3,14 & 3,22 \\
\hline
\end{tabular}

Keterangan: Data merupakan nilai rata-rata $\pm S D(n=2)$, huruf yang sama pada kolom menunjukkan tidak berbeda nyata pada taraf signifikan 0,05; GF: Garcinia forbesii (kulit manggis merah); GM: Garcinia mangostana (kulit manggis biasa)

Panas yang digunakan pada metode refluks dapat menyebabkan degradasi pada dinding sel sehingga memudahkan senyawa fenol keluar dan terekstrak serta pemanasan juga dapat menginaktivasi enzim polifenol oksidase sehingga dapat menurunkan kerusakan fenol, meningkatkan rendemen, dan meningkatkan stabilitas fenolnya (Susanti, 2008). Melalui metode ekstraksi dengan refluks (metode panas) dapat meningkatkan jumlah rendemen karena suhu panas yang dibutuhkan oleh pelarut etanol $70 \%$ untuk mencapai titik didih yang dapat malarutkan komponen zat aktif yang tidak terekstrak pada metode maserasi (metode tanpa panas) (Dewandari et al., 2013). Hasil pengukuran aktivitas antioksidan ekstrak Garcinia forbesil maupun Garcinia mangostana menunjukkan nilai aktivitas antioksidan tertinggi diperoleh menggunakan metode refluks 1 jam. Hasil tersebut disebabkan oleh refluks (metode panas) dapat meningkatkan jumlah rendemen karena suhu panas yang dibutuhkan oleh pelarut etanol $70 \%$ untuk mencapai titik didih yang dapat malarutkan komponen zat aktif yang tidak terekstrak pada metode maserasi (metode tanpa panas) (Dewandari et al., 2013). Selain itu, nilai aktivitas antioksidan pada metode refluks 3 jam lebih rendah dibandingkan dengan metode refluks 1 jam, hal ini dapat disebabkan walaupun panas dan pelarut etanol yang digunakan dapat mengoptimalkan ektraksi senyawa aktif, namun semakin lama waktu dan panas yang digunakan dalam ekstraksi dapat merusak antioksidan senyawa aktifnya. Salah satu antioksidan dalam kulit manggis yaitu flavonoid yang merupakan golongan fenol memiliki sistem konjugasi dapat mudah rusak pada suhu tinggi yang terlalu lama.

Senyawa fenolik memiliki aktivitas antioksidan karena gugus hidroksil fenolik mampu mereduksi senyawa radikal, namun tidak semua senyawa yang memiliki nilai aktivitas antioksidan merupakan senyawa fenolik. Hasil pengukuran TSF menjukkan bahwa ekstraksi dengan metode refluks 3 jam me- miliki nilai TSF yang lebih tinggi dibandingakan dengan metode maserasi. Menurut Randy (2014), kandungan air yang lebih tinggi pada Garcinia forbesii memberikan $\mathrm{pH}$ yang asam yang lebih tinggi karena kandungan asam organik yang sangat kuat seperti asam malat, asam tartarat, asam sitrat, dan asam asetat. Dalam penelitian ini, hasil analisis kandar vitamin C Garcinia forbesii sebesar 10,73 $\mathrm{mg} / \mathrm{g}$. Kandungan asam yang tinggi tersebut sangat berperan dalan memengaruhi nilai aktivitas antioksidannya karena kandungan asam organik yang lebih tinggi pada Garcinia forbesii dibandingkan dengan Garcinia mangostana, sehingga Garcinia forbesii memiliki nilai aktivitas antioksidan yang lebih tinggi (Randy, 2014).

\section{Sintesis nanopartikel kulit manggis}

Nanopartikel merupakan salah satu formulasi suatu partikel yang terdispersi pada ukuran nanometer. Kitosan merupakan polimer yang diperoleh dari hasil hidrolisis polimer kitin cangkang hewan laut (kepiting, udang). Kitosan lebih banyak dipilih karena memiliki sifat khas, yaitu kemampuan untuk membuka kait antar sel (tight junction) pada membran usus secara sementara (Masotti et al., 2007) sehingga sangat potensial dikembangkan sebagai bahan untuk pembuatan nanopartikel dalam aplikasi penghantar terkontrol suatu zat aktif. Selain itu, kitosan yang memiliki muatan positif pada gugus amonium dapat berinteraksi ionik dengan asam sialat pada membran intestinal saluran cerna (Vllasaliu et al., 2010). Kitosan juga bersifat biodegradable, biokompatibel, food grade, memiliki toksisitas yang rendah (alergi), dan metode preparasi yang sederhana. Batas maksimum penggunaan kitosan adalah CPPB (jumlah yang secukupnya diperlukan untuk menghasilkan efek yang diinginkan), sedangkan STPP memiliki batas penggunaan maksimum $70 \mathrm{mg} / \mathrm{kg}$ bb (BPOM, 2013). Kemampuan kitosan dalam pembuatan nanopartikel sudah banyak diteliti, di antaranya nanopartikel paclitaxel 
suatu obat antikanker dengan ukuran $116 \mathrm{~nm}$ ( $\mathrm{Li} J$ dan Qingrong Y, 2012); kombinasi 5-fluorourasil dan leucovorin suatu obat anti kanker kolon dengan ukuran partikel 40,73-78,53 $\mathrm{nm}$ ( $\mathrm{Li} \mathrm{J}$ dan Qingrong $Y, 2012$ ), deksametason natrium fosfat suatu obat antiinflamasi dengan ukuran partikel 250-350 nm (Dustgani et al., 2008).

Metode pembuatan nanopartikel kitosan yaitu dengan metode gelasi ionik. Sodium Tripolifosfat (STPP) merupakan salah satu poliaion yang banyak digunakan, dimana larut dalam air mengion membentuk ion hidroksil dan ion tripolifosfat (Kafshgari et al., 2011). Reaksi sambung silang secara ionik terjadi antara ion tripolifosfat (polianion) dan gugus amin - $\mathrm{NH} 3+$ (kation) kitosan (Ko $\mathrm{S}$ dan Lee SC, 2010). Semakin banyak terjadi reaksi sambung silang ionik antara kitosan dan STPP, maka semakin banyak molekul nanopartikel zat aktif yang terbentuk. Pada penelitian Yu-Hsin et al. (2008) melaporkan bahwa STPP sebagai polianion berinteraksi membentuk ikatan silang dengan kitosan yang bersifat kation akan membentuk nanopartikel yang lebih stabil dan memiliki penembusan membran yang lebih baik. STPP dipilih memiliki sifat food grade, lebih aman, dan tidak menimbulkan efek samping. Hasil pengujian nanopartikel Garcinia forbesii dan Garcinia mangostana (Gambar 1) terhadap karakteristik sifat fisik dan fungsional pada beberapa formula konsentrasi kitosan dan STPP dapat dilihat pada Tabel 2. Hasil analisis pada Tabel 2 menunjukkan formula F2 memiliki ukuran partikel terbaik karena paling kecil dibandingkan formula lainnya baik pada Garcinia forbesii (Gambar 2) maupun Garcinia mangostana (Gambar 3). Ukuran partikel nanopartikel yang disepakati secara umum memiliki ukuran di bawah 1 mikron atau $1000 \mathrm{~nm}$ (Buzea et al., 2007), namun ukuran dibawah $500 \mathrm{~nm}$ memiliki karakteristik yang lebih baik. Dalam penelitian ini formula F2 memberikan hasil yang terbaik, selanjutnya akan dilakukan enkapsulasi. Semakin tinggi konsentrasi kitosan dengan jumlah STPP yang sama menyebabkan peningkatan ukuran partikel disebabkan aglomerasi pada molekul kitosan, karena partikel yang terbentuk karena interaksi kitosan dan STPP lebih banyak dan semakin padat, sehingga partikel cenderung bergerombol dan beraglomerasi membentuk agregat menjadi partikel yang lebih besar berukuran mikro (Wahyono, 2010). Peningkatan ukuran partikel dipengaruhi oleh kondisi $\mathrm{pH}$, volume, dan kecepatan pengadukkan stirrer. Variasi $\mathrm{pH}$ akan memengaruhi ionisasi kitosan yang akan memengaruhi pada kekuatan ikatan pada kompleks nanopartikel yang terbentuk (Lopez-Leon et al., 2005). Pada $\mathrm{pH}$ rendah tripolifosfat banyak terionisasi ke dalam bentuk ion tripolifosfat dibandingkan dengan ion hidroksil, sedangkan pada $\mathrm{pH}$ basa sebaliknya, sehingga pada $\mathrm{pH}$ basa terbentuknya ikatan silang semakin rendah dan menyebabkan ukuran partikel menjadi lebih besar.

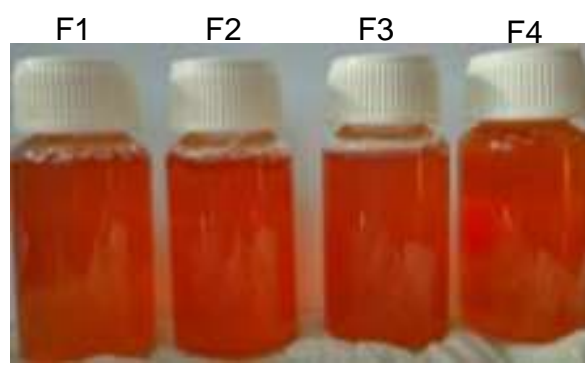

A

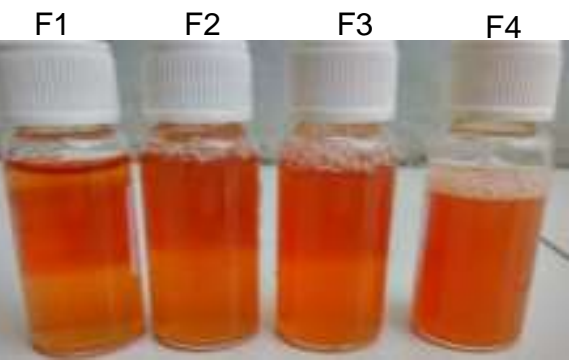

B

Gambar 1. Larutan nanopartikel ekstrak Garcinia forbesii (GF) (A) dan Garcinia mangostana (GM) (B)

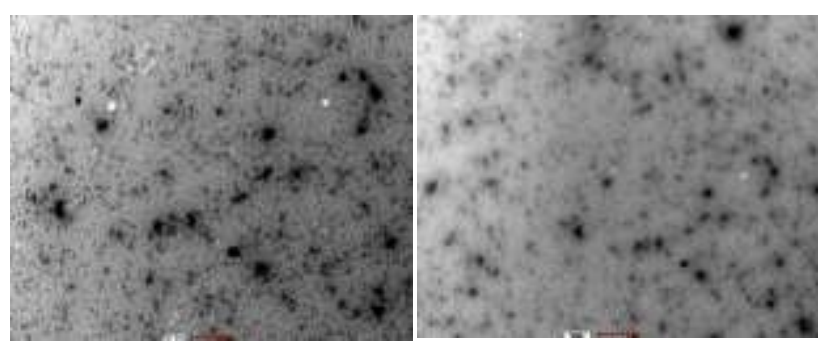

Gambar 2. Hasil analisis Transmission Electron Microscopy (TEM) nanopartikel ekstrak Garcinia forbesii (GF)

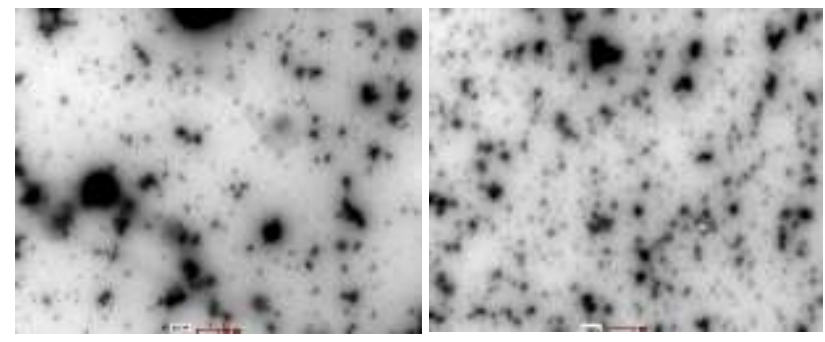

Gambar 3. Hasil analisis Transmission Electron Microscopy (TEM) nanopartikel ekstrak Garcinia mangostana (GM)

Nilai indeks polidispersitas menunjukkan keseragaman ukuran partikel. Menurut Yuan et al. (2008), semakin kecil nilai indeks polidispersitas maka ukuran partikel semakin homogen. Menurut Avadi et al. (2010), nilai indeks polidispersitas lebih besar dari 0,5 menunjukkan heterogenitas yang tinggi, dan sebaliknya jika mendekati nilai 0 menunjukkan ukuran partikel yang seragam. 
Table 2. Hasil analisis karakterisasi nanopartikel

\begin{tabular}{ccccc}
\hline Formula & $\begin{array}{c}\text { Ukuran Partikel } \\
(\mathrm{nm})\end{array}$ & $\begin{array}{c}\text { Indeks } \\
\text { Polidispersitas }\end{array}$ & $\begin{array}{c}\text { Aktivitas Antioksidan } \\
\text { AEAC }(\mu \mathrm{g} / \mathrm{mL})\end{array}$ & $\begin{array}{c}\text { Total Fenol GAE } \\
(\mu \mathrm{g} / \mathrm{mL})\end{array}$ \\
\hline F1 GF & $478,60 \pm 17,97^{\mathrm{a}}$ & $0,45 \pm 0,01^{\mathrm{a}}$ & $4854,17 \pm 287,72^{\mathrm{a}}$ & $1736,41 \pm 10,87^{\mathrm{a}}$ \\
F2 GF & $214,40 \pm 3,50^{\mathrm{b}}$ & $0,36 \pm 0,02^{\mathrm{b}}$ & $5729,17 \pm 198,74^{\mathrm{b}}$ & $1714,67 \pm 16,30^{\mathrm{a}}$ \\
F3 GF & $928,50 \pm 69,25^{\mathrm{c}}$ & $0,52 \pm 0,02^{\mathrm{c}}$ & $5104,17 \pm 313,88^{\mathrm{c}}$ & $1714,67 \pm 5,43^{\mathrm{a}}$ \\
F4 GF & $806,80 \pm 35,84^{\mathrm{a}}$ & $0,60 \pm 0,05^{\mathrm{a}}$ & $4104,17 \pm 90,81^{\mathrm{a}}$ & $1725,54 \pm 5,43^{\mathrm{a}}$ \\
F1 GM & $6897,00 \pm 252,0^{\mathrm{a}}$ & $1,00 \pm 0,00^{\mathrm{a}}$ & $4416,67 \pm 544,85^{\mathrm{a}}$ & $2766,30 \pm 19,02^{\mathrm{a}}$ \\
F2 GM & $285,20 \pm 5,99^{\mathrm{b}}$ & $0,46 \pm 0,01^{\mathrm{b}}$ & $4562,50 \pm 198,73^{\mathrm{a}}$ & $2711,96 \pm 13,58^{\mathrm{a}}$ \\
F3 GM & $764,80 \pm 65,08^{\mathrm{c}}$ & $0,62 \pm 0,03^{\mathrm{c}}$ & $3791,67 \pm 131,75^{\mathrm{b}}$ & $2875,00 \pm 8,15^{\mathrm{a}}$ \\
F4 GM & $1655,00 \pm 780,10^{\mathrm{d}}$ & $0,88 \pm 0,08^{\mathrm{d}}$ & $3020,83 \pm 108,25^{\mathrm{b}}$ & $2828,80 \pm 10,87^{\mathrm{a}}$ \\
\hline
\end{tabular}

Keterangan: Data merupakan nilai rata-rata $\pm S D(n=2)$, huruf yang sama pada kolom menunjukkan tidak berbeda nyata pada taraf signifikan 0,05; GF: Garcinia forbesii, GM: Garcinia mangostana; F1: 0,2\% kitosan dan 0,2\% STPP; F2: 0,2\% kitosan dan 0,1\% STPP; F3: $1 \%$ kitosan dan 0,2\% STPP; F4: 1\% kitosan dan 0,1\% STPP

Hasil pengujian indeks polidispersitas formula terpilih F2 pada Garcinia forbesii maupun Garcinia mangostana memiliki nilai indeks polidispersitas kurang dari 0,5. Hal ini menunjukkan ukuran partikel nanopartikel sampel formula F2 tersebut masih seragam. Ukuran partikel yang tidak seragam dapat disebabkan karena kecenderungan partikel untuk beraglomerasi membentuk agregat partikel yang lebih besar. Faktor yang menyebabkan hal tersebut dapat terjadi di antaranya adalah formula kombinasi kitosan dan STPP, pH larutan, kecepatan pengadukan stirrer, volume saat pengadukan dengan strirrer. Hasil analisis sifat fungsional tersebut dilakukan berdasarkan jumlah ekstrak sebesar $10 \%$ dari total larutan nanopartikel karena merupakan jumlah optimal dalam penerapan zat aktif dalam nanopartikel kulit manggis (Rismana et al., 2013). Berdasarkan jumlah ekstrak dalam larutan nanopartikel, nilai sifat fungsional nanopartikel mengalami peningkatan. Hal ini menunjukkan bahwa sintesis nanopartikel yang membuat ukuran partikel semakin kecil (berukuran nanometer) akan meningkatkan luas permukaan partikel sehingga permeabilitasnya meningkat, hal ini mengakibatkan aktivitas antioksidannya juga meningkat. Karakterisasi morfologi nanopartikel menggunakan TEM dapat dilihat pada (Gambar 2) yaitu nanopartikel ekstrak Garcinia forbesii (GF) dan (Gambar 3) yaitu ekstrak Garcinia mangostana (GM) menunjukkan bahwa bentuk nanopartikel kurang seragam. Hal ini dapat disebabkan karena pengaruh $\mathrm{pH}$ pada sampel, dimana $\mathrm{pH}$ nanopartikel Garcinia mangostana (GM) lebih tinggi dibandingkan dengan nanopartikel Garcinia forbesii (GF). Hal ini menyebabkan kekuatan ikatan ionik semakin rendah dan mengakibatkan kecenderungan unruk beraglomerasi membentuk agregat partikel yang lebih besar sehingga ukuran partikel menjadi lebih besar.

\section{Hasil spray drying nanopartikel ekstrak kulit manggis}

Enkapsulasi nanopartikel bertujuan meningkatkan kelarutan karena luas permukaannya yang besar, mengontrol pelepasan zat bioaktif dalam tubuh, serta melindungi dari interaksi dengan zat lain dalam bahan pangan (Ahmed et al., 2012). Penggunaan kombinasi bahan penyalut bertujuan untuk mendapatkan nanopartikel sebagai sistem penghantar zat aktif terkontrol yang lebih optimal. Maltodekstrin adalah polisakarida yang memiliki sifat yang baik sebagai bahan enkapsulan, aman, tidak toksis, dan memiliki batas penggunaan maksimumnya CPP (jumlah yang diperlukan secukupnya untuk menghasilkan efek yang diinginkan) (BPOM, 2013). Selain maltodekstrin, bahan penyalut seperti protein juga dapat digunakan karena sifat yang dapat membentuk gel sehingga memungkinkan sebagai bahan enkapsulasi zat aktif baik lipofilik maupun hidrofilik (Gunasekaran et al., 2007). Selain itu, menurut Chen et al. (2006) protein juga melindungi senyawa aktif yang sensitif terhadap kondisi di saluran pencernaan, sehingga dapat menjadi penghantar zat aktif secara terkontrol. Kasein dan isolat protein kedelai dipilih dalam penelitian ini sebagai kombinasi bahan penyalut karena ketersediaannya yang melimpah, lebih aman, tidak memiliki efek samping, dan murah. Hasil proses spray drying dapat memberikan rendemen yang berbeda, hal ini dipengaruhi oleh perbedaan nilai Dextrose Equivalent (DE), artinya nilai $D E$ yang lebih tinggi menimbulkan kecenderungan terjadinya karamelisasi yang semakin tinggi saat dilakukan spray dryer dengan suhu tinggi, sehingga banyak yang menempel di dinding tabung spray dryer yang mengakibatkan penurunan rendemen (Richana et al., 2007).

Hasil pengamatan morfologi permukaan enkapsulat nanopartikel GM (Gambar 4) dan GF (Gambar 5) dan dengan bahan penyalut MISP maupun MK terlihat morfologi permukaannya bulat, mengalami pengerutan, permukaan kasar, dan bentuknya cenderung tidak seragam. Hal ini disebabkan oleh adanya pengaruh panas pada saat proses spray drying, pengaruh perbandingan kombinasi bahan penyalut yang digunakan, laju alir evaporasi, dan besar tekanan pada saat spray drying. Hal ini juga dapat menyebabkan senyawa zat aktif dari nanopartikel GM dapat hilang karena tidak terperangkap dengan baik. Faktor yang memengaruhi bentuk morfologi bubuk enkapsulat menurut Harris et al. 
(2011) adalah suhu inlet dan laju evaporasi pelarut saat proses spray drying. Suhu pemanasan yang tinggi pada spray drying juga dapat menyebabkan hilangnya senyawa aktif sehingga permukaan menjadi lebih kasar, mengkerut, dan padat (Deladino et al., 2008).

A

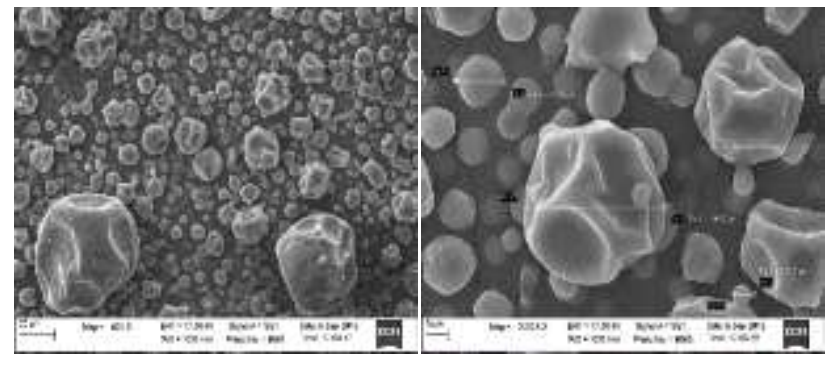

B

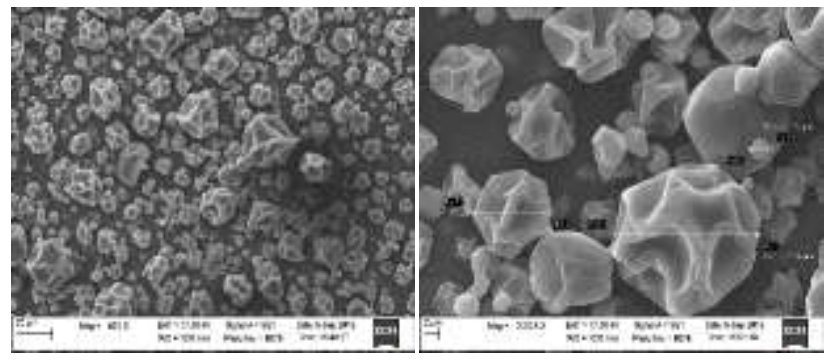

Gambar 4. Hasil analisis SEM enkapsulat nanopartikel ekstrak GM bahan penyalut MISP (maltodekstrin 60\% dan isolat protein $40 \%$ ) (A) dan MK (maltodekstrin $60 \%$ dan kasein $40 \%$ ) (B)

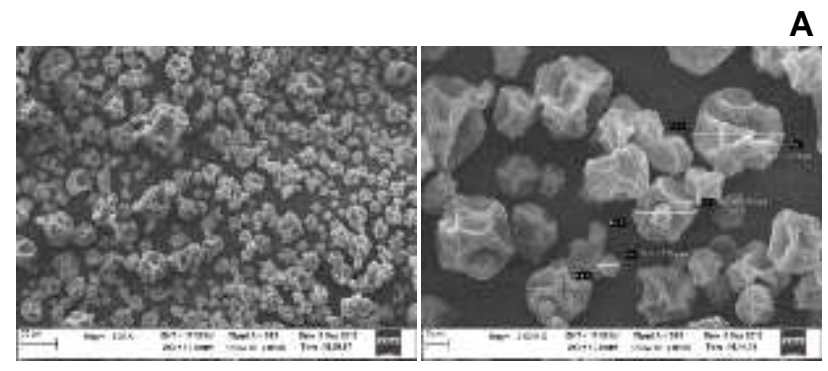

B
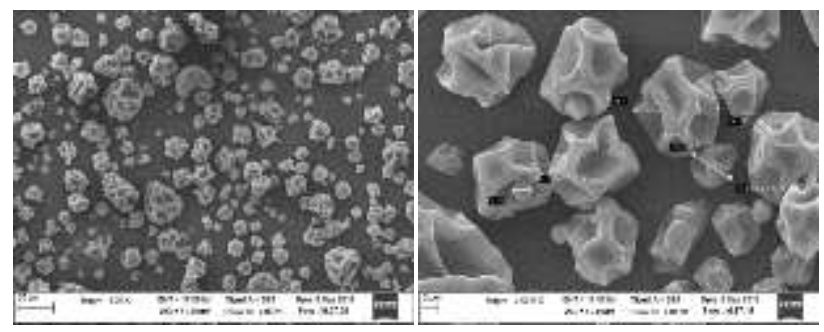

Gambar 5. Hasil analisis SEM enkapsulat nanopartikel ekstrak GF bahan penyalut MISP (maltodekstrin 60\% dan isolat protein $40 \%$ ) (A) dan MK (maltodekstrin $60 \%$ dan kasein $40 \%$ ) (B)
Pengerutan yang terjadi dari hasil enka-psulasi memengaruhi banyaknya senyawa zat aktif nanopartikel yang tersalut. Hal ini berkorelasi hasil analisis aktivitas antioksidan dan TSF keempat sampel bubuk enkapsulat tersebut. Pengujian aktivitas antioksidan dan TSF dilakukan untuk mengetahui apakah terjadi perubahan sifat fungsional selama proses spray drying. Perhitungan konsentrasi ekstrak yang digunakan adalah sebesar 10\% dalam larutan nanopartikel. Hasil analisis aktivitas antioksidan dan TSF dapat dilihat pada Tabel 3 . Hasil analisis menunjukkan perlakuan dengan bahan penyalut Maltodekstrin Kasein (MK) memberikan nilai sifat fungsional yang lebih tinggi dibandingkan dengan Maltodekstrin Isolat Protein Kedelai (MISP). Hal ini menunjukkan bahwa perlakukan dengan bahan penyalut MK dapat melindungi zat aktif dengan lebih baik dibandingkan dengan MISP. Semakin tinggi luas permukaan suatu partikel, semakin tinggi pula nilai aktivitas antioksidan dan TSF sampel. Dengan demikian, hal ini dapat menjadi pertimbangan untuk menurunkan penggunaan dosis nanopartikel dalam aplikasinya ke dalam pangan seperti minuman, karena dengan dosis yang kecil dapat memberikan nilai aktivitas antioksidan yang tinggi. Namun, perlu dikaji dalam penelitian selanjutnya terkait dengan dosis penggunaan nanopartikel ini dalam aplikasinya ke produk pangan, baik secara in vitro maupun in vivo.

Tabel 3. Hasil analisis sifat fungsional enkapsulat nanopartikel GF dan GM

\begin{tabular}{lccc}
\hline Sampel & $\begin{array}{c}\text { Metode } \\
\text { Perlakuan } \\
\text { Ekstraksi }\end{array}$ & $\begin{array}{c}\text { Aktivitas } \\
\text { Antioksidan } \\
(\mu \mathrm{g} / \mathrm{mL})\end{array}$ & $\begin{array}{c}\text { Total Senyawa } \\
\text { Fenol (TSF) } \\
(\mu \mathrm{g} / \mathrm{mL})\end{array}$ \\
\hline G. & $\mathrm{M}: \mathrm{ISP}$ & $4283,33 \pm$ & $1375,00 \pm$ \\
forbesii & $60 \%: 40 \%$ & $721,68^{\mathrm{a}}$ & $8,35^{\mathrm{a}}$ \\
& $\mathrm{M}: \mathrm{K}$ & $5550,00 \pm$ & $2896,74 \pm$ \\
& $60 \%: 40 \%$ & $223,61^{\mathrm{b}}$ & $84,33^{\mathrm{b}}$ \\
G. & $\mathrm{M}: \mathrm{ISP}$ & $3133,33 \pm$ & $1743,48 \pm$ \\
mango- & $60 \%: 40 \%$ & $317,98^{\mathrm{a}}$ & $54,67^{\mathrm{a}}$ \\
stana & $\mathrm{M}: \mathrm{K}$ & $5766,67 \pm$ & $2958,70 \pm$ \\
& $60 \%: 40 \%$ & $317,98^{\mathrm{b}}$ & $168,24^{\mathrm{b}}$ \\
\hline
\end{tabular}

Keterangan: Data merupakan nilai rata-rata $\pm S D(n=2)$, huruf yang sama pada kolom menunjukkan tidak berbeda nyata pada taraf signifikan 0,05; M: Maltodekstrin; ISP: Isolat protein; K: Kasein

\section{KESIMPULAN}

Ekstraksi dengan menggunakan metode refluks 1 jam memberikan hasil terbaik berdasarkan parameter rendemen dan sifat fungsionalnya. Formula 2 nanopartikel ekstrak Garcinia forbesii dan Garcinia mangostana terpilih yaitu konsentrasi kitosan $0,2 \%$ dan STPP $0,1 \%$ yang memberikan hasil sifat fisik dan fungsional yang terbaik dengan nilai ukuran partikel $214,4 \pm 3,51 \mathrm{~nm}$ dan $285,2 \pm 5,99 \mathrm{~nm}$. Hasil 
pengamatan morfologi permukaan enkapsulat nanopartikel yaitu bulat mengalami pengerutan, permukaan kasar, dan bentuknya cenderung tidak seragam. Perhitungan konsentrasi ekstrak yang digunakan sebesar $10 \%$ dalam larutan nanopartikel memberikan peningkatan nilai sifat fungsional. Hasil analisis sifat fungsional enkapsulat terbaik adalah dengan bahan penyalut MK yang menunjukkan zat aktif nanopartikel dapat terlindungi dengan baik. Dengan demikian, Formula 2 dan pembuatan nanopartikel dan enkapsulat dengan bahan penyalut MK memberikan peningkatan nilai fungsional.

\section{DAFTAR PUSTAKA}

Ahmed K, Yan L, David JM, Hang X. 2012. Nanoemulsion and emulsion based delivery system for curcumin: Encapsulation and release properties. Food Chem 132: 799-807. DOI: 10.101 6/j.foodchem.2011.11.039.

[AOAC] Association of Official Analytical Chemists. 2012. Official Methods of Analysis $16^{\text {th }}$ Ed. Arlington (US): Virginia A.

Apriyantono A, Fardiaz D, Puspitasari NL, Sedarnawati, Budiyanto S. 1989. Petunjuk Laboratorium Analisis Pangan. Bogor (ID): PAU Pangan dan Gizi Press.

Avadi MR, Assal MMS, Nasser M, Saideh A, Fatemeh A, Rassoul D, and Morteza R. 2010. Preparation and characterization of insulin nanoparticle using chitosan and arabic gum with ionic gelation method. Nanomed Nanotechnol 6: 58-63. DOI: 10.1016/j.nano.2009.04. 007.

[BPOM] Peraturan Kepala Badan Pengawas Obat dan Makanan. 2013. Peraturan Nomor 24 Tahun 2013 Tentang Bahan Tambahan Pangan Penstabil. Jakarta (ID): BPOM.

Buzea C, Pacheco II, and Robbie K. 2007. Nanomaterial and nanoparticle: sources and toxicity. Biointerphases 2: MR17. DOI: 10.1116/1.28 15690.

Chen L, Gabriel ER, Muriel S. 2006. Food proteinbased materials as nutraceutical delivery systems. Trends Food Sci Technol 17: 272-283. DOI: 10.1016/j.tifs.2005.12.011.

Deladino L, Anbinder PS, Navarro AS, and Martino MN. 2008. Encapsulation of natural antioxidants extracted from llex paraguariesnsis. Carbohyd Polym 71: 126-134. DOI: 10.1016/j.carbpol.20 07.05.030.

Dewandari KK, Yuliani S, Yasni S. 2013. Ekstraksi dan karakterisasi nanopartikel eksrak sirih merah (Piper crocatum). J Penel Pascapanen Pertanian 10: 65-71. DOI: 10.21082/jpasca. v10n2.2013.58-65.
Desai GH, Park HJ. 2005. Recent developments in microencapsulation of food ingredients. J Dry Technol 23: 1361-1394. DOI: 10.1081/drt-200 063478.

Dustgani A, Ebrahim V, Mohammad I. 2008. Preparation of chitosan nanoparticles loaded by dexamethasone phosphat. Iranian J Pharm Sci 4: 111-114.

Gunasekaran S, Sanghoon Ko, Lan Xiao. 2007. Use of whey protein foe encapsulation and controlled delivery applications. J Food Eng 83: 31 40. DOI: 10.1016/j.jfoodeng.2006.11.001.

Harris R, Lecumberri $E$, Mateos A, Mengibar M, Heras A. 2011. Chitosan nanoparticles and microsphere for the encapsulation of natural antioxidants extracted from llex paraguariensis. Carbohyd Polym 84: 803-806. DOI: 10.1016/j. carbpol.2010.07.003.

Kafshgari $\mathrm{MH}$, Khorram $\mathrm{M}$, Khodadoost $\mathrm{M}$, Khavari S. 2011. Reinforcement of chitosan nanoparticles obtained by an ionic cross-linking process. Iranian J Polym 20: 445-456.

Ko S, Lee SC. 2010. Effect of nanoliposomes on the stabilization of incorporated retinol. Afr $\mathrm{J}$ Biotechnol 9: 6158-6161.

Kubo I, Masuoka N, Xiao P, Haraguchi H. 2002. Antioxidant activity of dodecyl gallate. J Agr Food Chem 50: 3533-3539. DOI: 10.1021/ jf011250h.

Lako J, Trenerry VC, Wahlqvist M, Wattanapenpaiboon N, Sotheeswaran S, Premier R. 2007. Phytochemical flavonols, carotenoids and the oxidant properties of a wide selection of fijian fruit, vegetables and other readily available foods. Food Chem 101: 1727-1741. DOI: 10.10 16/j.foodchem.2006.01.031.

Li J, Qingrong Y. 2012. Rheological properties of chitosan-tripolyphosphate complexes: From suspensions to microgels. Carbohyd Polym 87: 1670-1677. DOI: 10.1016/j.carbpol.2011.09.07 4.

Lopez-Leon T, Carvalho ELS, Seijo B, OrtegaVinuesa JL, Bastos-Gozales D. 2005. Physicochemical characterization of chitosan nanoparticles: electrokinetic and stability behavior. J Colloid Interf Sci 238: 344-351. DOI: 10.1016/ j.jcis.2004.08.186.

Masotti A, Marino F, Ortaggi, Palocci C. 2007. Fluorescence and Scanning Electron Microscopy of Chitosan/DNA nanoparticles for applications. Modern Res Educational Topics Microscopy 690-696.

Mranani SA. 2015. Pemanfaatan Potensi Manggis Merah (Garcinia forbesii) sebagai Pengawet Alami dan Minuman Fungsional. [Skripsi]. 
Program Studi Ilmu dan Teknologi Pangan. Institut Pertanian Bogor.

Prasad KN, En Y, Chun Y, Mouming Z, Yueming J. 2009. Effects of high pressure exraction on the extraction yield, total phenolic content and antioxidant activity of longan fruit pericarp. Innov Food Sci Emerg 10: 155-159. DOI: 10.1016/j.ifset.2008.11.007.

Randy M. 2014. Kajian Pemanfaatan dan Pengembangan Potensi Ekstrak Manggis Merah (Garcinia Forbesii) Sebagai Minuman Fungsional Kaya Antioksidan dan Kestabilannya. [Skripsi]. Bogor (ID) Fakultas Teknologi Pertanian, Institut Pertanian Bogor.

Richana N, Fiena S, Pujoyuwono, Heti H. 2007. Optimasi Proses Produksi Maltodekstrin dan Tapioka Menggunakan Spray Drying. Prosiding Seminar Nasional Teknologi Inovatif Pascapanen Untuk Pengembangan Industri Berbasis Pertanian. Bogor (ID): Pascapanen Press.

Rismana E, Susi K, Olivia B, Idah R, Marahmah. 2013. Sintesis dan karakterisasi nanopartikel kitosan-ekstrak kulit manggis (Garcinia mangostana). J Penelitian Sains Teknol 14: 189-196.

Strychartz S, Shetty K. 2002. Peroxidase activity and phenolic content in elite clonal lines of Metha Pulegium in respense to polymeric dye $\mathrm{R}$ 478 and Agrobactericum rhizogenes. Process
Biochem 37: 805-812 DOI: 10.1016/s0032-959 2(01)00267-9.

Susanti DY. 2008. Efek Suhu Pengeringan terhadap Kandungan Fenolik dan Kandungan Katekin Ekstrak Daun Kering Gambir. Prosiding Seminar Nasional Teknik Pertanian Universitas Gajah Mada. Yogyakarta (ID): UGM Press.

Vllasaliu D, Hariis R, Heras A, Casettari L, Garnett M, Illum L, Stolnik S. 2010. Tight junction modulation by chitosan nanoparticles: Comparison with chitosan solution. Int J Pharma 400: 183-193. DOI: 10.1016/j.ijpharm.2010.08.020.

Wahyono D. 2010. Ciri Nanopartikel Kitosan dan Pengaruhnya pada Ukuran Partikel dan Efisiensi Penyalutan Ketoprofen. [Tesis]. Bogor (ID): Program Studi Kimia Sekolah Pascasarjana, Institut Pertanian Bogor.

Yuan Y, Gao Y, Zhao J, Mao L. 2008. Characterization and stability evaluation of $\beta$-carotene nanoparticles prepared by high pressure homogenization under various emulsifying conditions. Food Res Int 41: 61-68. DOI: 10.1016/j.food res.2007.09.006.

Yu-Hsin L, Kiran S, Kurt ML, Jyuhn HJ, Long F, Han Y, Hsing WS. 2008. Multi-ion-crosslinked nanoparticle with $\mathrm{pH}$-responsive charateristics for oral delivery of protein drugs. J Controlled Release 132: 141-149. DOI: 10.1016/j.jconrel.2008. 08.020 . 